\title{
Reclassifying Anaphylaxis to Neuromuscular Blocking Agents Based on the Presumed Patho-Mechanism: IgE-Mediated, Pharmacological Adverse Reaction or "Innate Hypersensitivity"?
}

\author{
David Spoerl ${ }^{1, *}$, Haig Nigolian ${ }^{1}$, Christoph Czarnetzki ${ }^{2}$ and Thomas Harr ${ }^{1}$ \\ 1 Division of Clinical Immunology and Allergy, Department of Medical Specialties, \\ University Hospital and Faculty of Medicine, University of Geneva, rue Gabrielle-Perret-Gentil 4, \\ CH-1205 Geneva, Switzerland; haig.nigolian@hcuge.ch (H.N.); thomas.harr@hcuge.ch (T.H.) \\ 2 Department of Anesthesiology, University Hospital and Faculty of Medicine, University of Geneva, \\ rue Gabrielle-Perret-Gentil 4, CH-1205 Geneva, Switzerland; Christoph.Czarnetzki@hcuge.ch \\ * Correspondence: david.spoerl@hcuge.ch; Tel.: +41-795-533-498
}

Academic Editors: Johannes Haybaeck and Werner Pichler

Received: 12 April 2017; Accepted: 2 June 2017; Published: 7 June 2017

\begin{abstract}
Approximately $60 \%$ of perioperative anaphylactic reactions are thought to be immunoglobulin IgE mediated, whereas $40 \%$ are thought to be non-IgE mediated hypersensitivity reactions (both considered non-dose-related type B adverse drug reactions). In both cases, symptoms are elicited by mast cell degranulation. Also, pharmacological reactions to drugs (type A, dose-related) may sometimes mimic symptoms triggered by mast cell degranulation. In case of hypotension, bronchospasm, or urticarial rash due to mast cell degranulation, identification of the responsible mechanism is complicated. However, determination of the type of the underlying adverse drug reaction is of paramount interest for the decision of whether the culprit drug may be re-administered. Neuromuscular blocking agents (NMBA) are among the most frequent cause of perioperative anaphylaxis. Recently, it has been shown that NMBA may activate mast cells independently from IgE antibodies via the human Mas-related G-protein-coupled receptor member X2 (MRGPRX2). In light of this new insight into the patho-mechanism of pseudo-allergic adverse drug reactions, in which as drug-receptor interaction results in anaphylaxis like symptoms, we critically reviewed the literature on NMBA-induced perioperative anaphylaxis. We challenge the dogma that NMBA mainly cause IgE-mediated anaphylaxis via an IgE-mediated mechanism, which is based on studies that consider positive skin test to be specific for IgE-mediated hypersensitivity. Finally, we discuss the question whether MRGPRX2 mediated pseudo-allergic reactions should be re-classified as type A adverse reactions.
\end{abstract}

Keywords: drug allergy; perioperative anaphylaxis; pseudo-allergy; adverse drug reaction; mast cell; histamine; Mas-related G-protein coupled receptor member X2

\section{Introduction}

The term "anaphylaxis" was previously used for IgE-mediated reactions only, whereas the term pseudo-allergic (or anaphylactoid) was used for similar clinical reactions, which occur via a non-IgE-dependent mechanism [1,2]. Both reactions may clinically present with hypotension, bronchospasm, and skin manifestations, typically urticaria [3,4]. The same symptoms might also be seen in cases of non-immune mediated pharmacological adverse drug reactions [5]. As it is not possible to distinguish anaphylactic from pseudo-allergic reactions clinically or by standard allergological investigations, a new definition has been suggested by the European Academy for 
Allergology and Clinical Immunology (EAACI). Thereby, all immediate-type adverse drug reactions are named anaphylaxis with a further subclassification into allergic or non-allergic [6].

The incidence of anaphylactic reactions during general anesthesia has been estimated at $1 / 4000$ to $1 / 25,000$, and about $1 / 5000$ for Neuromuscular blocking agents (NMBA) [7]. The incidence varies according to geographical factors [8], indicating that environmental factors might have an effect on the risk of anaphylaxis during anesthesia. Isolated cutaneous symptoms seem to be more frequent in non-IgE-mediated anaphylaxis, whereas bronchospasm and cardiovascular symptoms are more often seen in IgE-mediated anaphylaxis [2]. However, it has been shown that the anesthetist was able to correctly identify the culprit drug in only one third of all peri-operative reactions [9].

Skin tests have so far been considered to be specific for IgE-mediated hypersensitivity, whereas pseudo-allergic reactions have been considered to yield negative results. However, the term "pseudo-allergy" has been too frequently used to describe any kind of immediate-type allergic-like reaction that is not IgE-mediated [10]. This is particularly the case for non-steroidal anti-inflammatory drug (NSAID) adverse reactions, where skin tests are typically negative due to the lack of mast cell involvement.

The recent identification of the Mas-related G-protein-coupled receptor member X2 (MRGPRX2), now allows for better classification of different types of non-IgE mediated allergic reactions [11]. According to the EAACI nomenclature, which has been published prior to the description of the MRGPRX2 receptor, these reactions should be classified into non-IgE mediated, allergic hypersensitivity reactions, considering the mast cell as belonging to the immune system [6]. Despite the proposal of the EAACI to abandon the term "pseudo-allergy", this has been used to describe the reaction resulting from MRGPRX2 activation, and will be used in this review to differentiate this particular pathomechanism from other non-IgE mediated hypersensitivity reactions (Table 1). Especially, NMBA were described to elicit a pseudo-allergic reaction through activation of the MRGPRX2 receptor [11]. Whether this is relevant in human anaphylaxis to NMBA, remains hypothetical. However, this would explain why skin tests with NMBA may be positive in the absence of IgE-mediated hypersensitivity. Therefore, previously published data indicating that most reactions to NMBA are IgE-mediated based on positive skin test should be verified. An underlying pseudo-allergic mechanism would explain the high rate of anaphylactic reactions upon first exposure as well as the high rate of cross-sensitization, mainly demonstrated by positive skin test results to various NMBA [12,13].

A better understanding of the underlying mechanism is of clinical relevance for deciding whether the culprit drug may be re-administered or has to be avoided. According to the still generally accepted and widely used classification of adverse drug reactions (ADR) that was developed in the 1970s [14], ADR can be classified into dose-related (" $\mathrm{A}$ " for Augmented, type A) or non-dose-related reactions (" $\mathrm{B}$ " for Bizarre, type B). The frequency of ADR type A is approximately $80 \%$, whereas type $\mathrm{B}$ reactions are rarer [15]. According to this classification, non-IgE mediated hypersensitivity reactions represent type $B$ reactions $[16,17]$. However, the highly predictable and dose-dependent mast cell degranulation found upon MRGPRX2 activation by NMBA [11] would argue in favor of a re-classification of pseudo-allergic reactions as type A adverse reactions. This would then allow for a more confident re-administration of a specific drug if needed. 
Table 1. Distinguishing features and proposed classification of different immediate type hypersensitivity reactions.

\begin{tabular}{|c|c|c|c|c|c|}
\hline & $\begin{array}{c}\text { Pseudo-Allergic (Mas-Related } \\
\text { G-Protein-Coupled Receptor } \\
\text { Member X2 (MRGPRX2) } \\
\text { Activation) }\end{array}$ & $\begin{array}{c}\text { Non-IgE Mediated, Immunologic } \\
\text { Activation (IgG, rarely Described } \\
\text { to be Involved in Immediate } \\
\text { Type Reaction) }\end{array}$ & $\begin{array}{c}\text { Non-IgE Mediated, Non } \\
\text { Immunologic Activation } \\
\text { (i.e., Opioid, } \\
\text { Complement) }\end{array}$ & IgE Mediated & $\begin{array}{l}\text { Non-Allergic (Immune } \\
\text { System Not Primary } \\
\text { Involved) }\end{array}$ \\
\hline Mast cell involvement & Yes & Yes & Yes & Yes & No \\
\hline $\begin{array}{l}\text { Skin test (immediate } \\
\text { reading) }\end{array}$ & Positive & Negative & Positive & Positive & Negative \\
\hline Specific IgE & $\begin{array}{l}\text { Can be positive without clinical } \\
\text { relevance }\end{array}$ & $\begin{array}{l}\text { Can be positive without } \\
\text { clinical relevance }\end{array}$ & $\begin{array}{l}\text { Can be positive without } \\
\text { clinical relevance }\end{array}$ & Presumably positive & $\begin{array}{l}\text { Can be positive without } \\
\text { clinical relevance }\end{array}$ \\
\hline $\begin{array}{l}\text { Basophil activation test } \\
\text { (BAT) }\end{array}$ & $\begin{array}{l}\text { Can be positive without clinical } \\
\text { relevance }\end{array}$ & Presumably negative & For most negative & Presumably positive & Negative \\
\hline $\begin{array}{l}\text { Could explain reaction } \\
\text { after first time exposure }\end{array}$ & Yes & $\begin{array}{l}\text { No, except if previous sensitization } \\
\text { by cross-reactivity }\end{array}$ & Yes & $\begin{array}{l}\text { No, except if previous } \\
\text { sensitization by } \\
\text { cross-reactivity }\end{array}$ & Yes \\
\hline Dose dependency & Yes & Probably & Yes & $\begin{array}{c}\text { Classically no, marginally } \\
\text { significant }\end{array}$ & Yes \\
\hline $\begin{array}{l}\text { Adverse drug reactions } \\
\text { (ADR) Classification }\end{array}$ & New proposal: type A & Type B & Type B & Type B & Type A \\
\hline $\begin{array}{l}\text { Re-administration } \\
\text { possible }\end{array}$ & $\begin{array}{l}\text { Theoretically possible, with } \\
\text { reduced speed or lower doses. } \\
\text { No data available yet }\end{array}$ & Theoretically not recommended & $\begin{array}{l}\text { Theoretically not } \\
\text { recommended }\end{array}$ & $\begin{array}{c}\text { Not recommended } \\
\text { (consider desensitization } \\
\text { protocol) }\end{array}$ & $\begin{array}{l}\text { Yes, with reduced speed } \\
\text { or lower doses if not } \\
\text { pharmacologically } \\
\text { contraindicated }\end{array}$ \\
\hline
\end{tabular}




\section{Type A Adverse Drug Reactions Are Often Misinterpreted as Being "Allergic"}

Type A ADR are pharmacological adverse reactions, which typically do not involve the immune system, and are therefore predictable. This means that the drug may be re-administered with a lower dose or reduced speed without re-eliciting the same adverse reaction. Examples of type A ADR are diarrhea after antibiotics, or gastric ulcers following prolonged NSAID treatment. Also, toxic reactions are typical type A reactions. The reason why some individuals suffer from type A ADR, whereas others do not, is often unknown. Identifying type A ADR is important, since this will have implications for the future management of the patient. An incorrect labeling as "allergic" may result in withholding optimal treatment for a subsequent illness, which can be deleterious in infectious disease and in anesthetic procedures [15].

\section{Type B Adverse Drug Reaction Can Be Predictable and Dose Dependent}

Type B reactions are ADR that are not predictable. They mainly include hypersensitivity reactions, which are mediated by the immune system and occur in a susceptible subgroup of patients. This susceptibility is classically considered to be due to environmental factors, in particular previous exposure during which the adaptive immune system develops hypersensitivity. However, it has been increasingly noted that some type B reactions that are highly predictable were not due to environmental factors, but to the genetic profile of the patient, linked to particular human leukocyte antigens (HLA). The reason for this is that the antigen presentation to T-cells is dependent on specific HLA haplotypes, for example in abacavir, carbamazepine and allopurinol ADR, which seem to be dose-dependent [18,19].

\section{Mast Cells as Central Players in IgE-Mediated and Mas-Related G-Protein-Coupled Receptor Member X2-Mediated (MRGPRX2-Mediated) Anaphylactic Reactions}

Mast cells can release preformed mediators (histamine, serotonin and proteoglycans, mainly heparin), newly formed lipid mediators (thromboxane, prostaglandin D2, leukotriene C4) and cytokines (e.g., tumor necrosis factor alpha, interleukin-4) during anaphylactic reactions. The clinical picture of IgE-mediated hypersensitivity, including hypotension, bronchospasm and urticaria, is mainly caused by these mediators, in particular histamine. However, mast cell degranulation can be also elicited by other mechanisms than IgE crosslinking, as these cells carry a variety of other receptors on their surface that can induce degranulation (Figure 1). Mast cells can be activated by Toll-like receptors (TLR), protease-activated receptors (PARs), opioid receptor, complement (particularly C5a), IgG and under certain circumstances even T-cells, depending on the localization and type of mast cell $[20,21]$. Whether mast cells are antigen presenting cells, is still matter of debate. Whereas all human mast cell types are activated via the aggregation of high affinity IgE receptors (FceRI), a subset of mast cells found in the lungs and gut expressing only tryptase do not respond to complement components C3a, C5a and compound 48/80, a polymer used to promote mast cell degranulation [22]. Although TLR-mediated activation of mast cells does not lead to degranulation, but rather to cytokine, chemokine and lipid-mediator production, it is possible that TLR-mediated activation by pathogens may reduce the threshold required for degranulation by other stimuli [23]. 


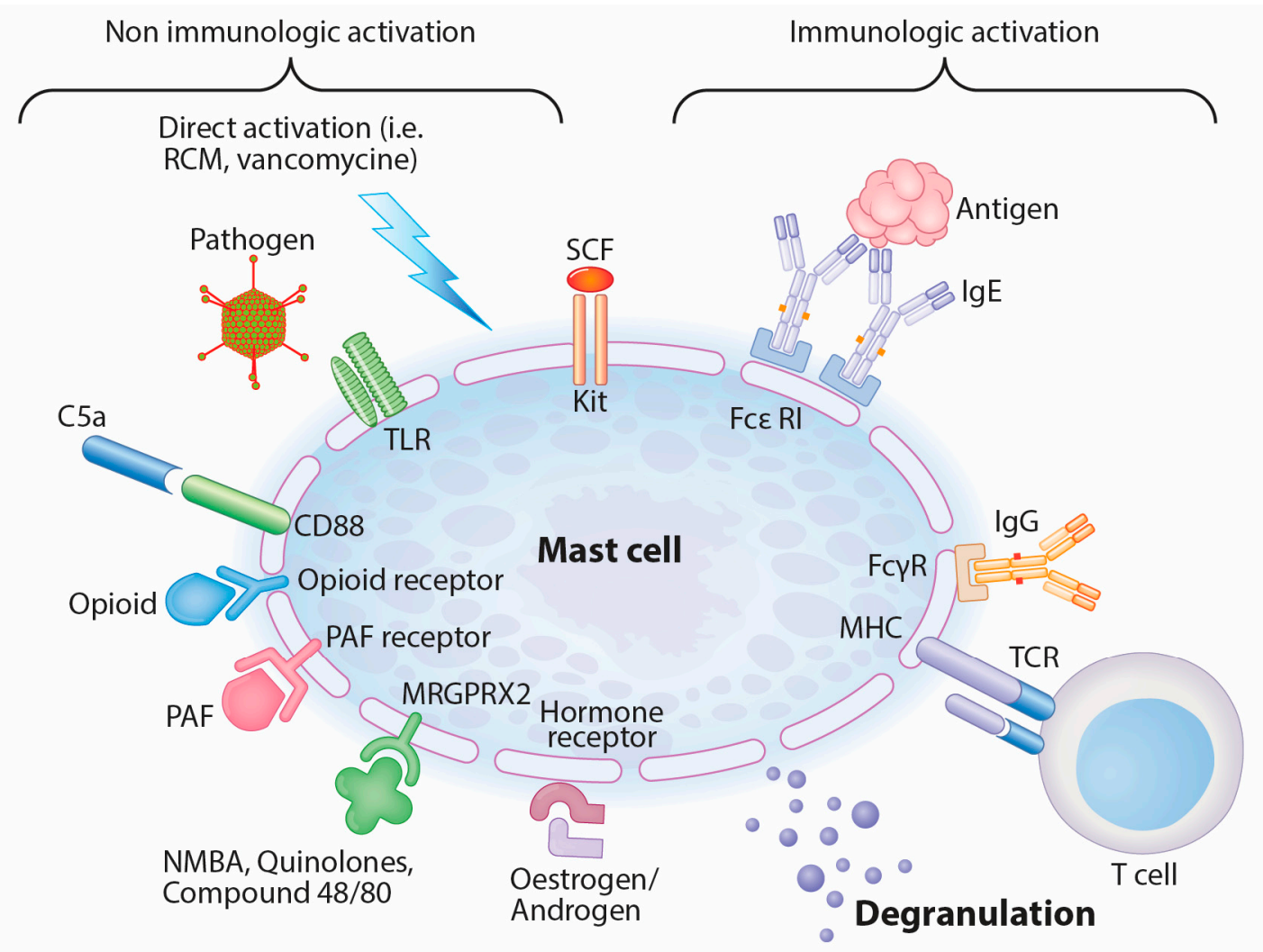

Figure 1. Immunologically and non-immunologically induced mast cell degranulation (adapted from Hannino et al. [20]). Abbreviations: RCM: radiocontrast media, TLR: Toll-like receptor, SCF: Stem cell factor, FceRI: high affinity IgE receptor, Fc $\gamma$ R: IgG receptor, TCR: T-cell receptor, NMBA: neuromuscular blocking agent, PAF: platelet activating factor, MHC: major histocompatibility complex.

\section{Mast Cells Can Be Stimulated by Various Co-Factors and Mas-Related G-Protein-Coupled Receptor Member X2 (MRGPRX2) Receptor Activation}

Patients with chronic spontaneous urticaria often suffer from flares caused rather by a non-IgE mediated mechanism than by IgE-mediated allergy [24]. Different eliciting co-factors have been described as possible triggers such as body temperature, infections, hormonal factors, alcohol, or foods. NSAID, opiates, iodinated contrast media, vancomycin, local anesthetics and NMBA represent possible mast cell triggering agents, and should be avoided in patients with chronic urticaria or systemic mastocytosis if possible [1,3,5,25-27]. In the recent EAACI position paper on mastocytosis, concerning the use of general anesthetics, the authors state that in the current limited literature, there is conflicting information on both the tolerance of and reactions to different single drugs and drug groups [25]. Other authors suggest to avoid mivacurium and atracurium in particular [28].

The combination of different co-factors is thought to have a cumulative effect. This means that a single co-factor alone does not necessarily lead to a clinically apparent mast cell degranulation, but the simultaneous presence of several co-factors have the potential to trigger symptoms mediated by histamine release in these patients [24]. Nevertheless, it is widely accepted that the responsible mechanism does not involve adaptive immunity, and hence does not require sensitization [20]. Similarly, MRGPRX2 induced mast cell degranulation could be considered a co-factor and as such, depend on the presence of other co-factors to be clinically relevant. This mechanism could in turn at least partially explain why only a minority of patients react to NMBA. 


\section{Anaphylactic Reactions upon First Exposure Might Be due to IgE Cross-Sensitization or a Pseudo-Allergic Reaction}

Therapeutically used monoclonal antibodies, as well as NMBA, have been described to induce anaphylactic reactions more frequently upon first exposure than subsequent re-exposure. The mechanism of these reactions remains unclear because previous sensitization to the drug is unlikely [29]. For decades, most NMBA were considered to cause non-specific histamine release from mast cells (benzylisoquinolines being more potent histamine releasers than aminosteroidal NMBA), and anesthetists believed that most of these reactions could be prevented by slow injection or pretreatment with antihistamines $[30,31]$. In recent years, newer studies from allergists, mainly considering positive skin test as a proof for IgE-mediated, type B ADR, indicated that for safety reasons, re-exposure to the culprit drug and to cross-reactive drugs needs to be avoided.

According to the current concept, a possible explanation for an IgE-mediated reaction upon first exposure could be cross-reactivity among different drugs, as shown in patients reacting to NMBA who have been previously exposed to pholcodine. Pholcodine is a non-prescription antitussive drug that contains a substituted ammonium ion (a moiety where the hydrogen atoms are substituted with other organic groups such as an alkyl group). Epidemiological studies have shown a correlation between the intake of pholcodine and the incidence of NMBA anaphylaxis. This is considered to be due to common substituted ammonium ions (tertiary and/or quaternary ammonium (QA) structures) which are found in a wide variety of chemical structures, including NMBA and pholcodine [8]. The main argument in favor of an IgE-mediated patho-mechanism in perioperative anaphylactic reactions due to NMBA is the reported decrease of the incidence of perioperative anaphylaxis after withdrawal of pholcodine from the market in Norway [32]. In this large cohort the total amount of NMBA exposure was not reported, instead official sales of NMBA in grams were used as indicator of exposure, showing a $12 \%$ decrease of NMBA exposure, and in particular a $28 \%$ decrease of succinylcholine exposure during the period studied [7]. Though the association between pholcodine exposure and NMBA anaphylaxis seems to be well established, the pathogenic mechanisms connecting these events remain yet to be elucidated [8]. In fact, it has been shown that pholcodine withdrawal was also associated with a decrease of total IgE levels [33], supporting the idea that pholcodine might be a potent "polysensitizer" (polyclonal IgE response) and may elicit NMBA sensitization by another mechanism than by sharing a common epitope. Precisely, mast cell responsiveness might be decreased due to lower circulating total IgE levels, as seen in patients after anti-IgE treatment. Based on this hypothesis, some authors considered the possibility that QA ions might be able to bind directly to immune receptors and stimulate cellular effectors in analogy to the " $\mathrm{p}-\mathrm{i}$ concept" of drug interaction with majorhistocompatibility complex molecules and T-cell receptors in delayed hypersensitivity reactions [8].

\section{The Supposed Involvement of the MRGPRX2 Receptor in Adverse Drug Reactions (ADR) to Neuromuscular Blocking Agent (NMBA) Leads to the Hypothesis of an Underlying "Innate Hypersensitivity"}

Whereas severe cutaneous ADR associated with particular HLA-types are mainly delayed ADR, the recent identification of the MRGPRX2 receptor has introduced the concept of a genetical, possibly innate, predisposition to develop immediate-type pseudo-allergic ADR. Although environmental influence by epigenetic modification is certainly possible, genetic variants in the MRGPRX2 gene have already been reported $[34,35]$. This gene has undergone recent changes during evolution, and eleven haplotypes have been described so far [36]. Three of the four human-specific sequence substitutions are located in extra-cellular domains of the receptor. As extra-cellular receptor domains are usually involved in ligand recognition, the three human-specific amino acid substitutions may markedly modify the interaction between this receptor and its ligands. It is therefore probable that, similarly to several HLA-subtypes associated with drug reactions with eosinophilia and systemic symptoms (DRESS) syndrome or Lyell syndrome, mutations in the MRGPRX2 gene may be associated with an increased risk for pseudo-allergic ADR. 


\section{Perioperative Anaphylaxis due to NMBA Revised}

NMBA are considered to be responsible for the majority of IgE-mediated reactions occurring during general anesthesia, followed by latex, antibiotics, hypnotics and opioids [37-39]. Opioids, like morphine, typically trigger non-IgE-mediated reactions [38]. Up to $85 \%$ of anaphylactic reactions occur in NMBA-naïve patients [40], and most of the NMBA-allergic patients show a high percentage of cross-reactivity, mostly based on skin tests results [41,42]. However, other authors reported a clinically lack of cross-reactivity between benzylisoquinolines and aminosteroids. Leysen et al. reported that, among 19 allergic patients to rocuronium, 15 were subsequently uneventfully exposed to a benzylisoquinoline [43]. Table 2 shows the most relevant studies indicating the mechanism of anaphylactic reactions to NMBA in chronological order. Most studies consider NMBA to mainly cause IgE-mediated reactions because positive skin tests were considered to prove the presence of $\operatorname{IgE}[2,43-45]$. These studies should now be critically reviewed because we know that skin test can be positive in non-IgE mediated hypersensitivity.

Table 2. Major clinical studies with data related to the prevalence and patho-mechanism of adverse drug reactions (ADR) to neuromuscular blocking agents (NMBA) (case series and case reports not considered).

\begin{tabular}{|c|c|}
\hline Title & Relevant Data and Remarks \\
\hline $\begin{array}{l}\text { Anaphylactic and anaphylactoid reactions } \\
\text { occurring during anesthesia in France in } \\
\text { 1999-2000 [2]. }\end{array}$ & $\begin{array}{l}\text { Anaphylactic and anaphylactoid reactions were diagnosed in } 518 \text { cases }(66 \%) \text { and } \\
271 \text { cases }(34 \%) \text {, respectively. The most common causes of anaphylaxis were NMBA } \\
(n=306,58.2 \%) \text {. Anaphylaxis was diagnosed on the basis of clinical history, skin tests, } \\
\text { and/or specific immunoglobulin E assay. In case of negative tests, an anaphylactoid } \\
\text { reaction was diagnosed. }\end{array}$ \\
\hline $\begin{array}{l}\text { Anaphylactic and anaphylactoid reactions } \\
\text { occurring during anaesthesia in France. } \\
\text { Seventh epidemiologic survey (January } \\
\text { 2001-December 2002) [46]. }\end{array}$ & $\begin{array}{l}\text { Anaphylactic and anaphylactoid reactions were diagnosed in } 491 \text { cases }(69 \%) \text { and } \\
221 \text { cases }(31 \%) \text {, respectively. The most common causes of anaphylaxis were NMBA } \\
(n=271,55 \%) \text {. Anaphylaxis was diagnosed on the basis of clinical history if skin tests were } \\
\text { positive or in case of elevated tryptase values and the presence of specific IgE. In case of } \\
\text { negative tests, an anaphylactoid reaction was diagnosed. }\end{array}$ \\
\hline $\begin{array}{l}\text { Anaphylaxis during Anesthesia in } \\
\text { Norway [47]. }\end{array}$ & $\begin{array}{l}\text { Eighty-three cases were examined: IgE-mediated anaphylaxis was established in } 71.1 \% \text { of } \\
\text { the cases, and NMBA were by far the most frequent culprit drug }(93.2 \%) \text {. IgE-mediated } \\
\text { anaphylaxis was identified based on a modified categorization grading of causality of the } \\
\text { IgE-mediated reactions (investigated by skin prick test, intradermal test, histamine } \\
\text { releasing test, specific IgE against morphine and P-aminophenyl phosphoryl choline) }\end{array}$ \\
\hline $\begin{array}{l}\text { Diagnosis of NMBA hypersensitivity } \\
\text { reactions using cytofluorimetric analysis } \\
\text { of basophils [49]. }\end{array}$ & $\begin{array}{l}\text { In } 47 \text { NMBA allergic patients, cytofluorimetric analysis of basophils was positive in } \\
17 \text { subjects. The diagnosis of allergy to NMBA was established from a characteristic clinical } \\
\text { history (urticaria, bronchospasm and/or anaphylactic shock a few minutes after the start } \\
\text { of anesthesia) and the positivity of NMBA skin tests. }\end{array}$ \\
\hline $\begin{array}{l}\text { Anaphylaxis during general anaesthesia: } \\
\text { one-year survey from a British allergy } \\
\text { clinic [50]. }\end{array}$ & $\begin{array}{l}\text { Out of the } 23 \text { patients who presented with anaphylaxis during anesthesia, } 15 \text { patients were } \\
\text { found to have a positive skin test to at least one NMBA. }\end{array}$ \\
\hline $\begin{array}{l}\text { Evaluation of a new routine diagnostic } \\
\text { test for IgE sensitization to NMBA [51]. }\end{array}$ & $\begin{array}{l}\text { In } 168 \text { patients exposed to NMBA, quaternary ammonium (QA)-specific IgE was found in } \\
84.2 \% \text { of skin test-positive reactors. The frequency of QA-specific IgE positivity was } \\
\text { significantly higher in skin test-negative reactors }(24.6 \%) \text { than in controls }(9.3 \%) \text {, } \\
\text { suggesting NMBA sensitivity. }\end{array}$ \\
\hline $\begin{array}{l}\text { IgE-sensitization to the cough suppressant } \\
\text { pholcodine and the effects of its } \\
\text { withdrawal from the Norwegian } \\
\text { market [32]. }\end{array}$ & $\begin{array}{l}\text { Methods used to identify NMBA induced anaphylaxis are not reported. Decrease of } \\
\text { perioperative anaphylaxis after pholcodine withdrawal was noted. However, the total } \\
\text { amount of NMBA usage was not reported. }\end{array}$ \\
\hline $\begin{array}{l}\text { Negative predictive value of skin tests to } \\
\text { NMBA [53]. }\end{array}$ & $\begin{array}{l}55 \text { patients were diagnosed with an allergy to NMBA, confirmed by clinical history, } \\
\text { presence of specific IgE and/or positive skin test. } 19 \text { of these } 55 \text { patients had a second } \\
\text { general anesthesia, } 13 \text { without NMBA and } 6 \text { using an NMBA for which skin tests were } \\
\text { negative. None had had a new reaction to the injected NMBA. }\end{array}$ \\
\hline
\end{tabular}


Table 2. Cont.

\begin{tabular}{|c|c|}
\hline Title & Relevant Data and Remarks \\
\hline $\begin{array}{l}\text { Perioperative allergic reactions: } \\
\text { experience in a Flemish referral } \\
\text { centre [54]. }\end{array}$ & $\begin{array}{l}\text { Out of } 119 \text { patients, a diagnosis of IgE-mediated reaction was established by skin tests } \\
\text { and/or specific IgE in } 76 \text { cases }(63.9 \%) \text {. The most common agents were NMBA }(61.8 \%) \text {. } \\
\text { The remaining } 43 \text { cases }(36.1 \% \text { ) were considered as non-IgE-mediated reactions. }\end{array}$ \\
\hline $\begin{array}{l}\text { Predictive value of allergy tests for NMBA: } \\
\text { tackling an unmet need [43]. }\end{array}$ & $\begin{array}{l}272 \text { patients with a history of perioperative allergy who had received a NMBA were } \\
\text { reported. From the } 47 \text { patients who were re-exposed to a NMBA, } 19 \text { were initially } \\
\text { diagnosed with suspected NMBA allergy, } 13 \text { had another IgE-mediated allergy suspected, } \\
\text { and in the remainder } 15, \text { no IgE-mediated allergy was identified (skin test, specific IgE and } \\
\text { BAT were used). Negative skin test and negative BAT assisted the selection of alternative } \\
\text { NMBA, which were well tolerated in all cases. }\end{array}$ \\
\hline $\begin{array}{l}\text { Six years without pholcodine; Norwegians } \\
\text { are significantly less IgE-sensitized and } \\
\text { clinically more tolerant to NMBA [7]. }\end{array}$ & $\begin{array}{l}\text { Five to } 10 \text { years after pholcodine withdrawal, very few, if any, individuals were } \\
\text { IgE-sensitized to QA ion, and only one case of NMBA-related anaphylaxis per 1-2 years } \\
\text { was reported. However, exposure decreased during time of observation and less } \\
\text { suxamethonium and more rocuronium were used. }\end{array}$ \\
\hline
\end{tabular}

\subsection{Skin Tests to NMBA Have to Be Evaluated with Caution}

Skin tests have been so far considered to have a high specificity for IgE-mediated reactions and to be negative in non-IgE mediated, immediate type reactions [2]. In NMBA induced anaphylaxis, this assumption was supported by the observation that most of the patients tolerate NMBA that were negative in skin test [56]. However, cases of a second anaphylactic reaction to a NMBA for which skin tests were negative, have been reported. In one case series, three patients among 192 who reacted to NMBA had a second anaphylactic reaction after re-administration of NMBA which resulted negative in skin test. Another patient had a minor hypersensitivity reaction to an NMBA for which skin tests were negative. Two other patients had additional reactions to NMBA for which they were not tested [42]. This ratio (6/192) is clearly higher than the incidence of anaphylactic reactions in NMBA-naïve patients (i.e., 1/5000), indicating an underlying increased risk of recurrence in these apparently predisposed patients, possibly linked to an underlying "innate" pseudo-allergic mechanism.

Moreover, patients with immediate type hypersensitivity against antibiotics, confirmed by positive skin test, have an increased risk for positive allergy skin tests for NMBA, independently from their atopic status [57]. This suggests a predisposition to positive skin tests to NMBA in a subgroup of patients without previously known NMBA exposure, possibly due to an underlying pseudo-allergic mechanism. Indeed, skin tests can be positive in patients with pseudo-allergic reactions, in particular when drugs are tested in so-called "irritative concentration" [41]. This seems in agreement with previous data from biopsies of positive skin test to NMBA, in which IgE did not appear to play any role [58]. The fact that most people do not react to non-irritative drug concentrations in skin tests, does not allow to assume that the patients which react have specific IgE against the drug. In a study investigating the cellular and humoral components of NMBA-induced anaphylactic reactions, the correlation between skin test reactivity to rocuronium and IgE to rocuronium was low. In contrast, striking correlation between IgE to rocuronium and skin test reactivity to succinylcholine was found $(p<0.001)$ [52]. This suggests that skin tests with rocuronium might not indicate IgE-mediated allergy, while skin tests to succinylcholine, a drug not acting on the MRGPRX2 receptor but sharing the QA epitope with rocuronium, could be more reliable for true NMBA IgE hypersensitivity. It also shows that IgE to rocuronium might be of lesser clinical relevance, as shown in other studies [43,52]. However, whether skin test with NMBA at correct concentrations may still be of value for IgE-mediated hypersensitivity, remains matter of debate. For rocuronium, a concentration 1/1000 $(0.01 \mathrm{mg} / \mathrm{mL})$ has 
been used in recent studies for intradermal testing and could increase specificity for IgE mediated hypersensitivity [59]. Also, it is not known if MRGPRX2 receptor on human mast cells might have a higher affinity to rocuronium than other NMBA, which could explain the higher rate of reactions to rocuronium than to other NMBA [59].

\subsection{In Vitro Analysis of NMBA Anaphylaxis Shows Conflicting Results as to the Underlying Mechanism}

Tryptase and histamine release are not specific for an IgE-mediated reaction [60,61]. Tryptase increase has been described to be more prominent in IgE-mediated reactions than in non-IgE mediated reactions, but these studies considered positive skin test to be diagnostic for IgE-mediated hypersensitivity $[2,55]$. Supposing that NMBA (except succinylcholine) might cause pseudo-allergic reactions, these data may be reinterpreted as follows: tryptase increase during the perioperative reaction is associated with an increased likelihood to have positive skin test, irrespective of whether this is mediated by IgE or not. This phenomenon is likely due to an increased propensity of degranulating mast cells during the perioperative reaction and during skin test.

As to other in vitro diagnostic tools, the value of specific IgE measurements for rocuronium, QA and morphine remains a matter of debate [8,43]. Although specific IgE against morphine appear to have the highest specificity for NMBA hypersensitivity, retrospective data confirm that an isolated positive result for morphine is not a reliable predictor for NMBA allergy [43,62,63]. In particular, specific IgE to morphine is not a good biomarker for sensitization to benzylisoquinolines [64]. In fact, IgE reactivity to tertiary and QA structures has been frequently found in the healthy general population [65]. Moreover, the overall rate of morphine sensitization is quite high, with a prevalence of $10 \%$ for patients with non-NMBA allergies and 5\% for healthy blood donors in Norway [8]. Although the existence of specific IgE recognizing substituted ammonium ions has been demonstrated based on a radioimmunoassay using a sepharose-alcuronium complex [66], there is no conclusive evidence that conjugation of NMBA or their metabolites to endogenous proteins might form antigenic complexes [29]. Moreover, there is no evidence for any functional role of these antibodies in perioperative anaphylaxis to NMBA in vivo.

Basophil activation test (BAT) appears to be more reliable than measurement of specific IgE $[43,44]$. If the MRGPRX2 receptor is not expressed on basophils, as presumed by some authors [22], BAT could allow to differentiate true IgE-mediated hypersensitivity to NMBA from pseudo-allergic reaction. More precisely, if BAT would be positive, this would signal true IgE hypersensitivity, while negative BAT would indicate a MRGPRX2 mediated mechanism in a given patient with history of NMBA anaphylaxis. A recent study favored true IgE-mediated anaphylaxis as being responsible for atracurium-induced anaphylaxis because BAT was positive in $5 / 8$ patients with positive skin tests [62]. In another study, BAT was positive in $11 / 12$ patients who suffered from rocuronium-induced anaphylaxis and who had positive skin tests, and in $0 / 8$ patients who tolerated rocuronium and had a negative skin test. This indicates that skin test and BAT results are often coherent and argue against an underlying pseudo-allergic mechanism [67]. However, recent data in literature calls these considerations into question: flow-cytometry studies of basophils recently showed that basophils express MRGPRX2 mainly intracellular [68], and further studies are required to determine this issue.

Atracurium ADR represents an exception among NMBA as the responsible epitope seems to be different than the ammonium ion in IgE-mediated reactions [69,70]. Moreover, taken together it seems that sensitization to atracurium occurs from different routes requiring a prior exposure. Whereas atracurium and mivacurium were already known to cause pseudo-allergic reactions [37], there is now evidence that members of all NMBA families except succinylcholine might cause pseudo-allergic reactions [11]. New data support previous study results showing the histamine releasing potential of several NMBA in healthy subjects, in particular of atracurium, mivacurium, tubocurarine, and to a lesser extent rocuronium [71].

\section{Discussion}

The recent discovery of the MRGPRX2 receptor gave important new insights into the patho-mechanism of pseudo-allergic ADR and questions a few old dogmas, in particular that skin 
tests are supposed to be specific for IgE-mediated reactions. Therefore, data in the literature reporting ADR based on positive skin tests have to be critically reviewed. Skin testing is not a formal proof for IgE-mediated reactions from the adaptive immune system. A positive skin test can mirror alternative activation pathways of cutaneous mast cell activation. Especially the assumption that anaphylaxis due to NMBA could be mainly IgE-mediated has to be questioned. On one hand the reported decreased incidence of anaphylaxis due to NMBA in Norway after pholcodine withdrawal and the often overlapping results of skin test and BAT, might argue in favor of an IgE-mediated reaction. On the other hand, as discussed in the previous chapters, these studies have several limitations and possible biases, and there are several facts that argue in favor of a pseudo-allergic mechanism: (1) most reactions occur upon first exposure, (2) there is a high rate of cross-sensitization to several NMBA, (3) specific IgE is present in non-allergic individuals without a clear causal link to the anaphylactic reaction, and (4) there is an increased risk of a second anaphylactic reactions to NMBA in skin test-negative patients with previous reaction to another NMBA compared to patients without previous reaction [42].

\section{Conclusions}

There is little doubt that IgE against the substituted ammonium ion might be induced by exposure to different chemical substances, i.e., pholcodine, that in turn puts the patient at risk for IgE-mediated anaphylaxis to succinylcholine due to cross-reactivity. However, the recent identification of the MRGPRX2 receptor indicates that other NMBA might induce mainly pseudo-allergic reactions. As mast cell degranulation mediated by MRGPRX2 was found to be dose-dependent and highly predictable [11], we propose that these pseudo-allergic reactions, differently than other non- $\operatorname{IgE}$ mediated allergic reactions in which skin test with immediate reading are negative (i.e., T-cell, IgG mediated, eosinophilic), should be reclassified as type A ADRs.

The hypothesis that most NMBA may cause pseudo-allergic rather than IgE-mediated reactions raises several new questions. (1) Supposing that NMBA reactions are due to non-IgE-mediated mast cell degranulation, why do some individuals react more easily than others? (2) Does the expression of MRGPRX2 vary in a single individual over time? Studies addressing the genetic variants and epigenetic modifications of MRGPRX2 are urgently needed to provide answers to these questions and gain more insight in the field of pseudo-allergic reactions.

Author Contributions: David Spoerl reviewed the literature, David Spoerl and Thomas Harr drafted the manuscript, Christoph Czarnetzki and Haig Nigolian helped in drafting the manuscript.

Conflicts of Interest: The authors declare no conflict of interest.

\section{Abbreviations}

NMBA

NSAID

EAACI

MRGPRX2

ADR

TLR(s)

PAR(s)

FceRI

QA

BAT

DRESS

RCM

SCF

FC $\gamma$ R

TCR

PAF

MHC
Neuromuscular blocking agents

Non steroidal anti-inflammatory drugs

European Academy for Allergology and Clinical Immunology

Mas-related G-protein coupled receptor member X2

Adverse drug reactions

Toll-like receptors

Protease-activated receptors

High affinity IgE receptors

Quaternary ammonium

Basophil activation test

Drug reaction with Eosinophilia and systemic symptoms

Radiocontrast media

Stem cell factor

IgG receptor

T-cell receptor

Platelet activating factor

Major histocompatibility complex 


\section{References}

1. Ewan, P.W.; Dugué, P.; Mirakian, R.; Dixon, T.A.; Harper, J.N.; Nasser, S.M. BSACI BSACI guidelines for the investigation of suspected anaphylaxis during general anaesthesia. Clin. Exp. Allergy J. Br. Soc. Allergy Clin. Immunol. 2010, 40, 15-31. [CrossRef] [PubMed]

2. Mertes, P.M.; Laxenaire, M.-C.; Alla, F. Groupe d'Etudes des Réactions Anaphylactoïdes Peranesthésiques Anaphylactic and anaphylactoid reactions occurring during anesthesia in France in 1999-2000. Anesthesiology 2003, 99, 536-545. [CrossRef] [PubMed]

3. Farnam, K.; Chang, C.; Teuber, S.; Gershwin, M.E. Nonallergic drug hypersensitivity reactions. Int. Arch. Allergy Immunol. 2012, 159, 327-345. [CrossRef] [PubMed]

4. Czech, W.; Schöpf, E.; Kapp, A. Release of sulfidoleukotrienes in vitro: Its relevance in the diagnosis of pseudoallergy to acetylsalicylic acid. Inflamm. Res. Off. J. Eur. Histamine Res. Soc. 1995, 44, $291-295$. [CrossRef]

5. Mali, S. Anaphylaxis during the perioperative period. Anesth. Essays Res. 2012, 6, 124-133. [CrossRef] [PubMed]

6. Johansson, S.G.; Hourihane, J.O.; Bousquet, J.; Bruijnzeel-Koomen, C.; Dreborg, S.; Haahtela, T.; Kowalski, M.L.; Mygind, N.; Ring, J.; van Cauwenberge, P.; et al. EAACI (the European Academy of Allergology and Cinical Immunology) nomenclature task force A revised nomenclature for allergy. An EAACI position statement from the EAACI nomenclature task force. Allergy 2001, 56, 813-824. [CrossRef] [PubMed]

7. De Pater, G.H.; Florvaag, E.; Johansson, S.G.O.; Irgens, Å.; Petersen, M.N.H.; Guttormsen, A.B. Six years without pholcodine; Norwegians are significantly less IgE-sensitized and clinically more tolerant to neuromuscular blocking agents. Allergy 2016. [CrossRef] [PubMed]

8. Brusch, A.M.; Clarke, R.C.; Platt, P.R.; Phillips, E.J. Exploring the link between pholcodine exposure and neuromuscular blocking agent anaphylaxis. Br. J. Clin. Pharmacol. 2014, 78, 14-23. [CrossRef] [PubMed]

9. Krøigaard, M.; Garvey, L.H.; Menné, T.; Husum, B. Allergic reactions in anaesthesia: Are suspected causes confirmed on subsequent testing? Br. J. Anaesth. 2005, 95, 468-471. [CrossRef] [PubMed]

10. Celik, G.; Pichler, W.; Adkinson, N.F. Drug Allergy. In Middleton's Allergy: Principles E Practice; Adkinson, N.F., Middleton, E., Eds.; Mosby/Elsevier: Philadelphia, PA, USA, 2009.

11. McNeil, B.D.; Pundir, P.; Meeker, S.; Han, L.; Undem, B.J.; Kulka, M.; Dong, X. Identification of a mast-cell-specific receptor crucial for pseudo-allergic drug reactions. Nature 2015, 519, 237-241. [CrossRef] [PubMed]

12. Ebo, D.G.; Fisher, M.M.; Hagendorens, M.M.; Bridts, C.H.; Stevens, W.J. Anaphylaxis during anaesthesia: Diagnostic approach. Allergy 2007, 62, 471-487. [CrossRef] [PubMed]

13. Dewachter, P.; Mouton-Faivre, C.; Emala, C.W. Anaphylaxis and anesthesia: Controversies and new insights. Anesthesiology 2009, 111, 1141-1150. [CrossRef] [PubMed]

14. Rawlins, M.; Thompson, J. Pathogenesis of adverse drug reactions. In Textbook of Adverse Drug Reactions; Davies, D.M., Ed.; Oxford University Press: Oxford, UK; New York, NY, USA, 1977.

15. Waller, D.G. Allergy, pseudo-allergy and non-allergy. Br. J. Clin. Pharmacol. 2011, 71, 637-638. [CrossRef] [PubMed]

16. Edwards, I.R.; Aronson, J.K. Adverse drug reactions: Definitions, diagnosis, and management. Lancet Lond. Engl. 2000, 356, 1255-1259. [CrossRef]

17. Pichler, W. Drug allergy: Classification and clinical features. In UpToDate; Adkinson, N.F., Feldweg, A.M., Eds.; UpToDate: Waltham, MA, USA, 2016.

18. Yun, J.; Mattsson, J.; Schnyder, K.; Fontana, S.; Largiadèr, C.R.; Pichler, W.J.; Yerly, D. Allopurinol hypersensitivity is primarily mediated by dose-dependent oxypurinol-specific $\mathrm{T}$ cell response. Clin. Exp. Allergy 2013, 43, 1246-1255. [CrossRef] [PubMed]

19. Stamp, L.K.; Taylor, W.J.; Jones, P.B.; Dockerty, J.L.; Drake, J.; Frampton, C.; Dalbeth, N. Starting dose is a risk factor for allopurinol hypersensitivity syndrome: A proposed safe starting dose of allopurinol. Arthritis Rheum. 2012, 64, 2529-2536. [CrossRef] [PubMed]

20. Hennino, A.; Bérard, F.; Guillot, I.; Saad, N.; Rozières, A.; Nicolas, J.-F. Pathophysiology of urticaria. Clin. Rev. Allergy Immunol. 2006, 30, 3-11. [CrossRef] 
21. D'Andrea, M.R.; Rogahn, C.J.; Andrade-Gordon, P. Localization of protease-activated receptors-1 and -2 in human mast cells: Indications for an amplified mast cell degranulation cascade. Biotech. Histochem. 2000, 75, 85-90. [CrossRef] [PubMed]

22. Subramanian, H.; Gupta, K.; Ali, H. Roles of Mas-related G protein-coupled receptor X2 on mast cell-mediated host defense, pseudoallergic drug reactions, and chronic inflammatory diseases. J. Allergy Clin. Immunol. 2016, 138, 700-710. [CrossRef] [PubMed]

23. Marshall, J.S. Mast-cell responses to pathogens. Nat. Rev. Immunol. 2004, 4, 787-799. [CrossRef] [PubMed]

24. Zuberbier, T.; Pfrommer, C.; Specht, K.; Vieths, S.; Bastl-Borrmann, R.; Worm, M.; Henz, B.M. Aromatic components of food as novel eliciting factors of pseudoallergic reactions in chronic urticaria. J. Allergy Clin. Immunol. 2002, 109, 343-348. [CrossRef] [PubMed]

25. Bonadonna, P.; Pagani, M.; Aberer, W.; Bilò, M.B.; Brockow, K.; Oude Elberink, H.; Garvey, L.; Mosbech, H.; Romano, A.; Zanotti, R.; et al. Drug hypersensitivity in clonal mast cell disorders: ENDA/EAACI position paper. Allergy 2015, 70, 755-763. [CrossRef] [PubMed]

26. Zuberbier, T.; Asero, R.; Bindslev-Jensen, C.; Walter Canonica, G.; Church, M.K.; Giménez-Arnau, A.M.; Grattan, C.E.H.; Kapp, A.; Maurer, M.; Merk, H.F.; et al. Dermatology Section of the European Academy of Allergology and Clinical Immunology; Global Allergy and Asthma European Network; European Dermatology Forum; World Allergy Organization EAACI/GA (2) LEN/EDF/WAO guideline: Management of urticaria. Allergy 2009, 64, 1427-1443. [CrossRef] [PubMed]

27. Zuberbier, T.; Chantraine-Hess, S.; Hartmann, K.; Czarnetzki, B.M. Pseudoallergen-free diet in the treatment of chronic urticaria. A prospective study. Acta Derm. Venereol. 1995, 75, 484-487. [PubMed]

28. Dewachter, P.; Castells, M.C.; Hepner, D.L.; Mouton-Faivre, C. Perioperative management of patients with mastocytosis. Anesthesiology 2014, 120, 753-759. [CrossRef] [PubMed]

29. Baldo, B.A.; Fisher, M.M.; Pham, N.H. On the origin and specificity of antibodies to neuromuscular blocking (muscle relaxant) drugs: An immunochemical perspective. Clin. Exp. Allergy 2009, 39, 325-344. [CrossRef] [PubMed]

30. Moss, J. Muscle relaxants and histamine release. Acta Anaesthesiol. Scand. Suppl. 1995, 106, 7-12. [CrossRef] [PubMed]

31. Claudius, C.; Garvey, L.H.; Viby-Mogensen, J. The undesirable effects of neuromuscular blocking drugs. Anaesthesia 2009, 64 (Suppl. S1), 10-21. [CrossRef] [PubMed]

32. Florvaag, E.; Johansson, S.G.O.; Irgens, Å.; de Pater, G.H. IgE-sensitization to the cough suppressant pholcodine and the effects of its withdrawal from the Norwegian market. Allergy 2011, 66, 955-960. [CrossRef] [PubMed]

33. Florvaag, E.; Johansson, S.G.O.; Oman, H.; Harboe, T.; Nopp, A. Pholcodine stimulates a dramatic increase of IgE in IgE-sensitized individuals. A pilot study. Allergy 2006, 61, 49-55. [CrossRef] [PubMed]

34. Kaminsky, E.B.; Kaul, V.; Paschall, J.; Church, D.M.; Bunke, B.; Kunig, D.; Moreno-De-Luca, D.; Moreno-De-Luca, A.; Mulle, J.G.; Warren, S.T.; et al. An evidence-based approach to establish the functional and clinical significance of copy number variants in intellectual and developmental disabilities. Genet. Med. 2011, 13, 777-784. [CrossRef] [PubMed]

35. Miller, D.T.; Adam, M.P.; Aradhya, S.; Biesecker, L.G.; Brothman, A.R.; Carter, N.P.; Church, D.M.; Crolla, J.A.; Eichler, E.E.; Epstein, C.J.; et al. Consensus statement: Chromosomal microarray is a first-tier clinical diagnostic test for individuals with developmental disabilities or congenital anomalies. Am. J. Hum. Genet. 2010, 86, 749-764. [CrossRef] [PubMed]

36. Yang, S.; Liu, Y.; Lin, A.A.; Cavalli-Sforza, L.L.; Zhao, Z.; Su, B. Adaptive evolution of MRGX2, a human sensory neuron specific gene involved in nociception. Gene 2005, 352, 30-35. [CrossRef] [PubMed]

37. Nel, L.; Eren, E. Peri-operative anaphylaxis. Br. J. Clin. Pharmacol. 2011, 71, 647-658. [CrossRef] [PubMed]

38. Galvão, V.R.; Giavina-Bianchi, P.; Castells, M. Perioperative anaphylaxis. Curr. Allergy Asthma Rep. 2014, 14, 452. [CrossRef] [PubMed]

39. Laxenaire, M.C.; Mertes, P.M. Groupe d'Etudes des Réactions Anaphylactoïdes Peranesthésiques Anaphylaxis during anaesthesia. Results of a two-year survey in France. Br. J. Anaesth. 2001, 87, 549-558. [CrossRef] [PubMed]

40. Fisher, M.M.; Munro, I. Life-threatening anaphylactoid reactions to muscle relaxants. Anesth. Anal. 1983, 62, 559-564. [CrossRef] 
41. Spoerl, D.; D'Incau, S.; Roux-Lombard, P.; Harr, T.; Czarnetzki, C. Non-IgE-Dependent Hypersensitivity to Rocuronium Reversed by Sugammadex: Report of Three Cases and Hypothesis on the Underlying Mechanism. Int. Arch. Allergy Immunol. 2016, 169, 256-262. [CrossRef] [PubMed]

42. Fisher, M.M.; Merefield, D.; Baldo, B. Failure to prevent an anaphylactic reaction to a second neuromuscular blocking drug during anaesthesia. Br. J. Anaesth. 1999, 82, 770-773. [CrossRef] [PubMed]

43. Leysen, J.; Uyttebroek, A.; Sabato, V.; Bridts, C.H.; de Clerck, L.S.; Ebo, D.G. Predictive value of allergy tests for neuromuscular blocking agents: Tackling an unmet need. Clin. Exp. Allergy 2014, 44, 1069-1075. [CrossRef] [PubMed]

44. Hagau, N.; Gherman-Ionica, N.; Sfichi, M.; Petrisor, C. Threshold for basophil activation test positivity in neuromuscular blocking agents hypersensitivity reactions. Allergy Asthma Clin. Immunol. 2013, 9, 42. [CrossRef] [PubMed]

45. Dong, S.W.; Mertes, P.M.; Petitpain, N.; Hasdenteufel, F.; Malinovsky, J.M. GERAP Hypersensitivity reactions during anesthesia. Results from the ninth French survey (2005-2007). Minerva Anestesiol. 2012, 78, 868-878. [PubMed]

46. Mertes, P.-M.; Laxenaire, M.-C. GERAP (Anaphylactic and anaphylactoid reactions occurring during anaesthesia in France. Seventh epidemiologic survey (January 2001-December 2002)). Ann. Fr. Anesth. Reanim. 2004, 23, 1133-1143. [CrossRef] [PubMed]

47. Harboe, T.; Guttormsen, A.B.; Irgens, A.; Dybendal, T.; Florvaag, E. Anaphylaxis during anesthesia in Norway: A 6-year single-center follow-up study. Anesthesiology 2005, 102, 897-903. [CrossRef] [PubMed]

48. Karila, C.; Brunet-Langot, D.; Labbez, F.; Jacqmarcq, O.; Ponvert, C.; Paupe, J.; Scheinmann, P.; de Blic, J. Anaphylaxis during anesthesia: Results of a 12-year survey at a French pediatric center. Allergy 2005, 60, 828-834. [CrossRef] [PubMed]

49. Kvedariene, V.; Kamey, S.; Ryckwaert, Y.; Rongier, M.; Bousquet, J.; Demoly, P.; Arnoux, B. Diagnosis of neuromuscular blocking agent hypersensitivity reactions using cytofluorimetric analysis of basophils. Allergy 2006, 61, 311-315. [CrossRef] [PubMed]

50. Chong, Y.Y.; Caballero, M.R.; Lukawska, J.; Dugué, P. Anaphylaxis during general anaesthesia: One-year survey from a British allergy clinic. Singap. Med. J. 2008, 49, 483-487.

51. Laroche, D.; Chollet-Martin, S.; Léturgie, P.; Malzac, L.; Vergnaud, M.-C.; Neukirch, C.; Venemalm, L.; Guéant, J.-L.; Roland, P.N. Evaluation of a new routine diagnostic test for immunoglobulin E sensitization to neuromuscular blocking agents. Anesthesiology 2011, 114, 91-97. [CrossRef] [PubMed]

52. Aalberse, R.C.; Kleine Budde, I.; Mulder, M.; Stapel, S.O.; Paulij, W.; Leynadier, F.; Hollmann, M.W. Differentiating the cellular and humoral components of neuromuscular blocking agent-induced anaphylactic reactions in patients undergoing anaesthesia. Br. J. Anaesth. 2011, 106, 665-674. [CrossRef] [PubMed]

53. Ramirez, L.F.; Pereira, A.; Chiriac, A.M.; Bonnet-Boyer, M.-C.; Demoly, P. Negative predictive value of skin tests to neuromuscular blocking agents. Allergy 2012, 67, 439-441. [CrossRef] [PubMed]

54. Antunes, J.; Kochuyt, A.-M.; Ceuppens, J.L. Perioperative allergic reactions: Experience in a Flemish referral centre. Allergol. Immunopathol. Madr. 2014, 42, 348-354. [CrossRef] [PubMed]

55. Krishna, M.T.; York, M.; Chin, T.; Gnanakumaran, G.; Heslegrave, J.; Derbridge, C.; Huissoon, A.; Diwakar, L.; Eren, E.; Crossman, R.J.; et al. Multi-centre retrospective analysis of anaphylaxis during general anaesthesia in the United Kingdom: Aetiology and diagnostic performance of acute serum tryptase. Clin. Exp. Immunol. 2014, 178, 399-404. [CrossRef] [PubMed]

56. Soetens, F.M.; Smolders, F.J.; Meeuwis, H.C.; Van der Donck, A.G.; van der Aa, P.H.; De Vel, M.A.; Vanhoof, M.J.; Soetens, M.A. Intradermal skin testing in the investigation of suspected anaphylactic reactions during anaesthesia-A retrospective survey. Acta Anaesthesiol. Belg. 2003, 54, 59-63. [PubMed]

57. Hagau, N.; Gherman, N.; Cocis, M.; Petrisor, C. Antibiotic-induced immediate type hypersensitivity is a risk factor for positive allergy skin tests for neuromuscular blocking agents. Allergol. Int. 2016, 65, 52-55. [CrossRef] [PubMed]

58. Berg, C.M.; Heier, T.; Wilhelmsen, V.; Florvaag, E. Rocuronium and cisatracurium-positive skin tests in non-allergic volunteers: Determination of drug concentration thresholds using a dilution titration technique. Acta Anaesthesiol. Scand. 2003, 47, 576-582. [CrossRef] [PubMed]

59. Reddy, J.I.; Cooke, P.J.; van Schalkwyk, J.M.; Hannam, J.A.; Fitzharris, P.; Mitchell, S.J. Anaphylaxis is more common with rocuronium and succinylcholine than with atracurium. Anesthesiology 2015, 122, $39-45$. [CrossRef] [PubMed] 
60. Veien, M.; Szlam, F.; Holden, J.T.; Yamaguchi, K.; Denson, D.D.; Levy, J.H. Mechanisms of nonimmunological histamine and tryptase release from human cutaneous mast cells. Anesthesiology 2000, 92, 1074-1081. [CrossRef] [PubMed]

61. Marone, G.; Stellato, C.; Mastronardi, P.; Mazzarella, B. Mechanisms of activation of human mast cells and basophils by general anesthetic drugs. Ann. Fr. Anesth. Reanim. 1993, 12, 116-125. [CrossRef]

62. Uyttebroek, A.P.; Sabato, V.; Leysen, J.; Bridts, C.H.; De Clerck, L.S.; Ebo, D.G. Flowcytometric diagnosis of atracurium-induced anaphylaxis. Allergy 2014, 69, 1324-1332. [CrossRef] [PubMed]

63. Leysen, J.; de Witte, L.; Sabato, V.; Faber, M.; Hagendorens, M.; Bridts, C.; de Clerck, L.; Ebo, D. IgE-mediated allergy to pholcodine and cross-reactivity to neuromuscular blocking agents: Lessons from flow cytometry. Cytom. B Clin. Cytom. 2013, 84, 65-70. [CrossRef] [PubMed]

64. Fisher, M.M.; Baldo, B.A. Immunoassays in the diagnosis of anaphylaxis to neuromuscular blocking drugs: The value of morphine for the detection of IgE antibodies in allergic subjects. Anaesth. Intensive Care 2000, 28, 167-170. [PubMed]

65. Decuyper, I.I.; Ebo, D.G.; Uyttebroek, A.P.; Hagendorens, M.M.; Faber, M.A.; Bridts, C.H.; de Clerck, L.S.; Sabato, V. Quantification of specific IgE antibodies in immediate drug hypersensitivity: More shortcomings than potentials? Clin. Chim. Acta 2016, 460, 184-189. [CrossRef] [PubMed]

66. Baldo, B.A.; Fisher, M.M. Substituted ammonium ions as allergenic determinants in drug allergy. Nature 1983, 306, 262-264. [CrossRef] [PubMed]

67. Ebo, D.G.; Bridts, C.H.; Hagendorens, M.M.; Mertens, C.H.; de Clerck, L.S.; Stevens, W.J. Flow-assisted diagnostic management of anaphylaxis from rocuronium bromide. Allergy 2006, 61, 935-939. [CrossRef] [PubMed]

68. Sabato, V.; van Gasse, A.; Cop, N.; Claesen, K.; Decuyper, I.I.; Faber, M.A.; Bridts, C.; Mertens, C.; Hagendorens, M.; de Clerck, L.; et al. The Mas-Related G Protein-Coupled Receptor MRGPRX2 Is Expressed on Human Basophils and up-Regulated upon Activation. In Proceedings of the AAAAI Conference, Atlanta, GA, USA, 3-6 March 2017. Abstract 536.

69. Johansson, S.G.O.; Oman, H.; Degerbeck, F.; Tunelli, J.; Florvaag, E.; Nopp, A. Anaphylaxis to atracurium-A non-QAI-dependent reaction? Acta Anaesthesiol. Scand. 2012, 56, 262-263. [CrossRef] [PubMed]

70. Uyttebroek, A.P.; Sabato, V.; Bridts, C.H.; De Clerck, L.S.; Ebo, D.G. Immunoglobulin E antibodies to atracurium: A new diagnostic tool? Clin. Exp. Allergy J. Br. Soc. Allergy Clin. Immunol. 2015, 45, 485-487. [CrossRef] [PubMed]

71. Naguib, M.; Samarkandi, A.H.; Bakhamees, H.S.; Magboul, M.A.; El-Bakry, A.K. Histamine-release haemodynamic changes produced by rocuronium, vecuronium, mivacurium, atracurium and tubocurarine. Br. J. Anaesth. 1995, 75, 588-592. [CrossRef] [PubMed] 